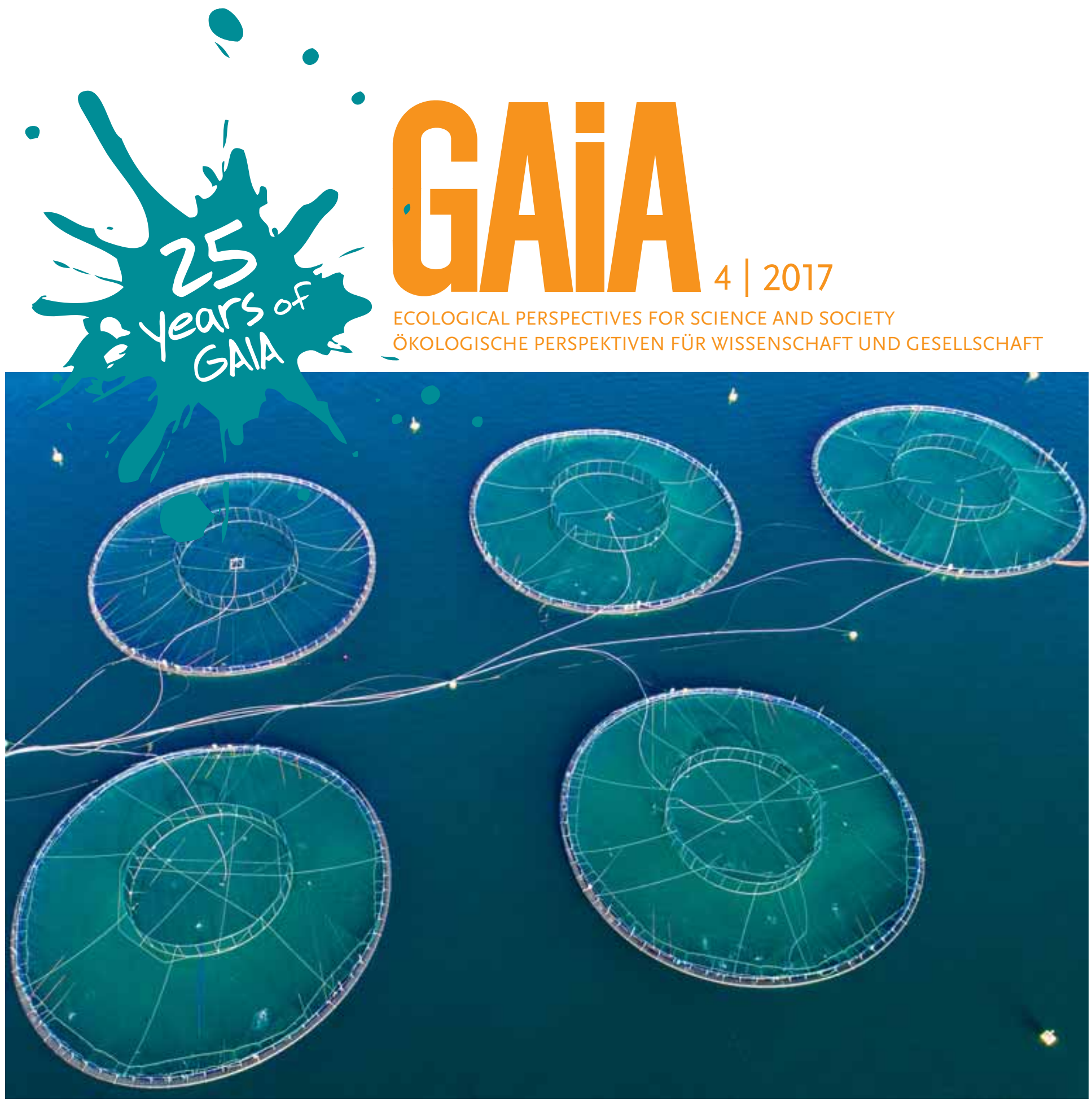

- SUSTAINABLE AQUACULTURE

- EXNOVATION OF UNSUSTAINABLE TECHNOLOGIES

- TRANSDISZIPLINÄRE FORSCHUNG REVISITED 


\section{Integrating Interdisciplinarity and Internationality in Sustainable Development Education}

\section{Allianz NACHHALTIGE UNIVERSITÄTEN in Österreich}

Thomas Brudermann, Robert Holländer, Roberto Pastres, Alfred Posch, Paul Schot

\begin{abstract}
Growing awareness of environmental and social issues in economic development contributes to move the idea of sustainable development forward. Since 2008, the Joint International Master in Sustainable Development offers an international and interdisciplinary approach to the hotly debated topic. It combines the strengths of the eight partner universities in Europe, Asia and Africa.
\end{abstract}

Integrating Interdisciplinarity and Internationality in Sustainable Development Education | GAIA 26/4 (2017): 360-362

Keywords: higher education, interdisciplinarity, Master Programme, sustainability, transdisciplinarity

D riven by environmental pressures (e.g., climate change, biodiversity loss, land use change) and global-scale social issues

Contact authors: Ass.-Prof. DI Dr. Thomas Brudermann (corresponding author) | E-Mail: thomas.brudermann@uni-graz.at

Ao. Prof. Dr. Alfred Posch |

E-Mail: alfred.posch@uni-graz.at

both: University of Graz | Institute of Systems Sciences, Innovation and Sustainability Research | Graz | Austria

Prof. Dr.-Ing. Robert Holländer | University of Leipzig | Chair Environmental Technology and Environmental Management in SME | Leipzig | Germany | E-Mail: hollaender@wifa.uni-leipzig.de

Assoc. Prof. Roberto Pastres, PhD | Ca' Foscari University di Venezia | Department of Physical Chemistry | Venice | Italy | E-Mail: pastres@unive.it

Assoc. Prof. Dr. Paul Schot | Utrecht University | Copernicus Institute of Sustainable Development | Utrecht | The Netherlands | E-Mail: p.p.schot@uu.nl

Contact Alliance of Sustainable Universities in Austria: Vice Rector Prof. Dr. Josef Glössl | University of Natural Resources and Life Sciences, Vienna (BOKU) | Gregor-Mendel-Str. 33 | 1180 Vienna | Austria | Tel.: +4314765410112 |

E-Mail: rektorat@boku.ac.at

C 2017 T. Brudermann at al.; licensee oekom verlag. This is an article distributed under the terms of the Creative Commons Attribution License (http://creativecommons.org/licenses/by/3.0), which permits unrestricted use, distribution, and reproduction in any medium, provided the original work is properly cited. (e.g., inequality, poverty, mass migration), current and upcoming political agendas have no choice but need to evolve around sustainable development principles. The formulation of the 17 Sustainable Development Goals (SDGs) by the United Nations in the framework of the 2030 Agenda for Sustainable Development is reflecting the increasing relevance of sustainable development in international discussions. The EU, which issued its first sustainable development strategy in 2001, committed itself to the SDGs and recently set out a strategic approach for achieving sustainable development. ${ }^{1}$

Implementing respective strategies will require a broad coalition of policy makers, governments, nongovernmental organizations, several industry sectors and civil society. Universities and higher education institutions will play a crucial role; after all, these institutions are the ones that educate future decision makers and therefore are responsible for disseminating the knowledge and skills which are necessary to move forward sustainable development.

\section{Higher Education on Sustainable Development}

Challenges related to sustainable development cannot be sufficiently addressed from a mono-disciplinary perspective: economic, social and environmental objectives need to be integrated in a holistic way in scientific analysis, governance, problem solving, and human action (Sachs 2015). Sustainable development issues are characterized by a high degree of complexity, resulting from mutual interactions between social, economic, and biophysical systems (Bootsma et al. 2014). Consequently, mono-disciplinary approaches quickly are stretched to their limits, failing to offer sufficient explanatory value and feasible practical guidance. Instead it is vital to integrate knowledge and competencies from diverse backgrounds, by combining various social and natural sciences.

Therefore, study programmes on sustainable development need to take into account different perspectives and systems thinking; the traditional mono-disciplinary approaches need to be overcome to cope with highly complex and ill-defined problems of sustainable development (Posch and Steiner 2006). Providers of sustainable development education seem to be largely aware of this requirement; a recent study found that there is a rather high degree of inter- and transdisciplinarity in respective programmes (Vermeulen et al. 2014).

1 http://europa.eu/rapid/press-release_IP-16-3883_en.htm 
However, the integration of inter- and transdisciplinarity is only one of the necessary pillars of sustainable development education: sustainable development challenges go beyond national borders, thus strongly requiring international cooperation as well. It only is obvious to also organize respective academic education accordingly, that means through cross-disciplinarity and international cooperation.

\section{Joint International Master in Sustainable Development}

The Joint International Master in Sustainable Development is attending to these principles and trains students in linking the various knowledge domains which are relevant for addressing sustainability issues. Five European and three non-European universities, all with extensive experience in the field of sustainability science, have joined forces in implementing the programme: degrees are awarded by the University of Graz (Austria), the University of Leipzig (Germany), Utrecht University (Netherlands) and Ca'Foscari University of Venice (Italy). The consortium is completed by associated mobility partners, namely the University of $\mathrm{Ba}$ sel (Switzerland), Hiroshima University (Japan), Stellenbosch University (South Africa), and TERI University (India). personal experience of diversity and interdisciplinary, to the need for cooperation between global north and south, and to the need for communication between distinct scientific and professional cultures. The pan-European perspective offered by the European universities in the programme is enriched by partners from India, Japan, and South Africa.

The programme furthermore comes with a large degree of flexibility to accommodate different student interests as well as backgrounds; students can choose between specializations in natural science or social science tracks. Therefore, the target group for this programme involves motivated students who have a basic understanding of either natural or social sciences and recognize the relevance of sustainable development topics.

\section{Structure of the Joint International Master} The Joint International Master in Sustainable Development is a full time master programme (120 ECTS, four semesters). ${ }^{2}$

In the first semester, students attend a basic module at their chosen entrance university (Graz, Leipzig, Utrecht, or Venice). The objective is to provide students with an introduction to the concept of sustainable development and its history, key sustain-

\section{The Joint International Master prepares students to contribute to a transition towards sustainable development.}

The programme not only addresses the application of specialized scientific knowledge, but also the integration of such knowledge into different perspectives on sustainability challenges and potential solutions. It offers an interdisciplinary and international approach to sustainable development based on the individual strengths of the partner universities.

As a research master the programme prepares students for providing scientifically grounded inputs into national, sectoral, supranational, and nongovernmental sustainable development strategies. Moreover, it by design exposes students to the able development issues, policy analysis and assessment as well as approaches to environmental governance and operational tools. A focus also is placed on the complexity and dynamics of interactions between natural, social, and economic processes and systems on different scales.

The second semester comprises a mandatory mobility semester; that is, students attend a specialization track at one of the partner universities. The consortium offers specialization tracks from social and nat-

2 Detailed information: www.jointdegree.eu/sd.

\section{KAPP-FORSCHUNGSPREIS}

FÜR

ÖKologische ÖKonomie

AUSSCHREIBUNG 2018

Der Kapp-Forschungspreis für Ökologische Ökono mie richtet sich an junge Wissenschaftlerinnen und Wissenschaftler im deutschsprachigen Raum und soll Studien zur Ökologischen Ökonomie fördern. Für die Ausschreibung 2018 lautet die übergeordnete Themenstellung erneut:

"Wirtschaft ohne Wachstum"

Von Interesse sind wissenschaftliche Beiträge, die sich den Wachstumsursachen und -zwängen moderner Ökonomien, der (Un-)Vereinbarkeit wirt schaftlichen Wachstums mit nachhaltiger Entwicklung sowie den Merkmalen und möglichen Funktionsweisen einer Wirtschaft ohne Wachstum widmen.

Berücksichtigt werden folgende Kategorien von Arbeiten:

1. Dissertationen und Habilitationsschriften.

2. Diplom- und Masterarbeiten (keine Bachelorarbeiten)

Die Veränderungen, die für eine Wirtschaft ohne Wachstum erforderlich sind, können kaum aus einer rein wirtschaftswissenschaftlichen Perspektive allein begründet werden; deshalb sind interund transdisziplinär angelegte Arbeiten (in deutscher oder englischer Sprache) bei diesem Thema besonders naheliegend.

Das Preisgeld wird auf mehrere, in der Regel maximal zwei Preisträger/-innen verteilt und beträgt insgesamt

\subsection{Euro}

Interessierte erhalten die Bewerbungsunterlagen über die Geschäftsstelle des Kapp-Forschungspreises (Adresse siehe unten). Die Bewerbungsfrist endet mit dem

\section{März 2018}

Die Preisträger werden von einer unabhängigen Jury ausgewählt. Der Rechtsweg ist ausgeschlossen.

Der Kapp-Forschungspreis wird gemeinsam ausgeschrieben von:

der Vereinigung für Ökologische Ökonomie (VÖÖ) e.V., der Hatzfeldt-Stiftung, der KappStiftung, der Selbach-Umwelt-Stiftung sowie der anstiftung.

Anforderung der Bewerbungsunterlagen Dr. Manuel Schneider Projektbüro! make sense!, Waltherstr. 29, D-80337 München info@make-sense.org 
ural sciences; for instance, students may study Sustainable Business Management in Graz, Resources Management in Leipzig, Global Environmental Change in Venice, or Environmental Change and Ecosystems in Utrecht. Another option is to take a specialization track offered by the mobility partners in Basel and Hiroshima.

In the third semester, students return to their entrance university to attend an integration module which aims to integrate the interdisciplinary sustainable development concepts and disciplinary perspectives. In contrast to the disciplinary specialization in the second semester, the emphasis here clearly is on interdisciplinary thinking and problem solving, and therefore on the integration of diverse approaches and methods and intense discourse with other scientific disciplines. Students are enabled to apply the knowledge and scientific skills on complex issues and to strive for tangible outcomes in inter- and transdisciplinary teams; the module also includes the development and training of social skills, such as teamwork, conflict management, and project management. In addition to that, students also have the opportunity to complete a second mobility semester at one of the partner universities, including TERI University and Stellenbosch University.

The programme is completed with a master thesis (30 ECTS) in the fourth semester. The thesis is being assessed by the respective supervisor of the student at the entrance university as well as a second reader who is affiliated with one of the other consortium universities and has not been responsible for supervision. In this way, two independent assessments of the thesis are established, guaranteeing a fair and transparent grading, and simultaneously ensuring a high scientific quality of the research and also further integrating research between the consortium universities.

\section{Experiences and Lessons Learned}

Given the interactive nature of the study programme, only a limited number of students is being accepted to the programme starting each year in October (maximum 15 to 20 per university per year); in order to be admitted, prospective students need to apply online by end of March, and are being informed regarding acceptance after a careful selection process, which usually is completed in May. In recent years, the programme received approximately 200 to 300 applications per year, of which around 25 percent were finally admitted. The international and interdisciplinary nature of the programme attracts students from all over the world - in the winter term 2017 students from 25 countries and five continents joined the programme (see figure 1).

Students definitely benefit from the integrative and multi-disciplinary approach, which strengthens open-mindedness and allows developing fast response skills to complex challenges to be faced in profes-

FIGURE 1: Welcome meeting for new students from seven European countries, the USA and Bangladesh starting the Joint International Master in Sustainable Development in Graz (2017).

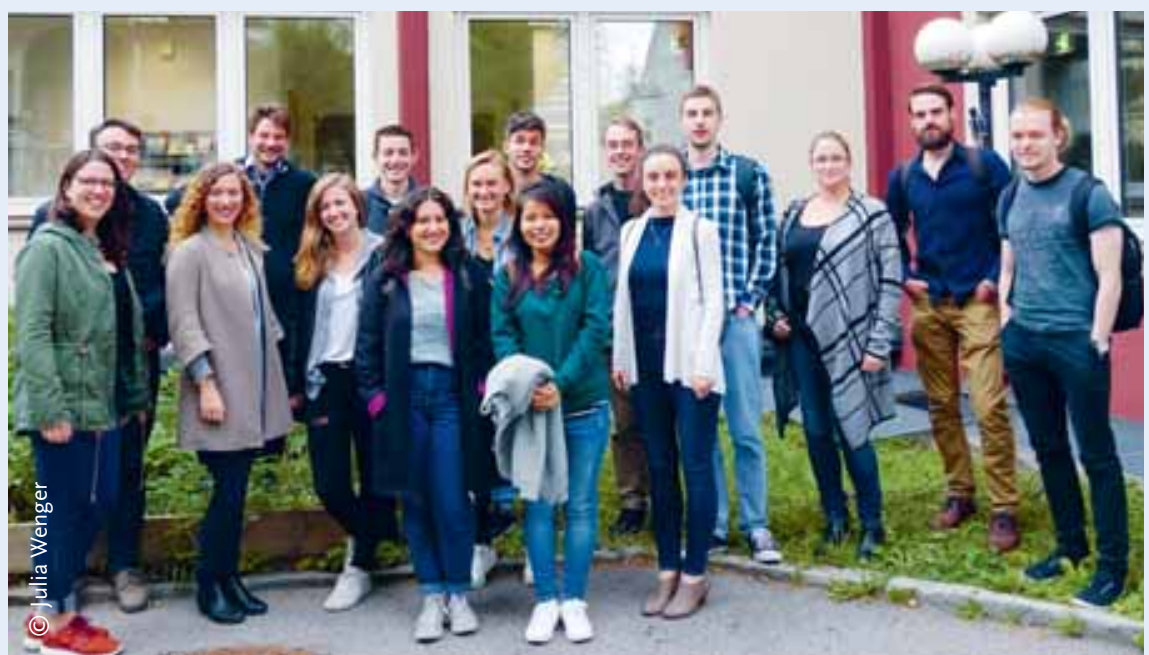

sional careers. The international approach of this programme enhances intercultural understanding and brings internationally experienced young professionals to the international labor markets.

What's more, also the participating universities benefit from the programme; the diversity in the classrooms undoubtedly affects teaching in a positive manner, and the teaching staff is challenged to extend their perspectives. Also the students in local programmes, who share several courses with students in the Joint Master Programme, benefit from discussions and from the different perspectives brought to the table by the international students. Moreover, the programme facilitates knowledge transfer among the participating universities, with positive effects not only on teaching, but also on research cooperation.

The ultimate aim, however, is to enable successful students to significantly contribute to a transition towards sustainable development, and looking at the career paths of alumni, the programme seems to deliver on its promises: "sustainers" today hold management positions in innovative and green companies, they founded start-ups and became sustainability entrepreneurs; "sustainers" furthermore are working for governmental and nongovernmental organizations or as policy consultants; and a significant share of alumni also used their SD master degree as a starting point in pursuing an academic career. Spreading out to such diverse domains definitely can be considered as one big success of the first ten years of the programme.

\section{References}

Bootsma, M.C., W. J. V. Vermeulen, J. van Dijk, P.P. Schot. 2014. Added value and constraints of transdisciplinary case studies in environmental science curricula. Corporate Social Responsibility and Environmental Management 21/3: 155-166.

Posch, A., G. Steiner. 2006. Integrating research and teaching on innovation for sustainable development. International Journal of Sustain ability in Higher Education 7/3: 276-292.

Sachs, J. 2015. The age of sustainable development. New York: Columbia University Press.

Vermeulen, W. J. V., M. C. Bootsma, M. Tijm. 2014. Higher education level teaching of (master's) programmes in sustainable development: Analysis of views on prerequisites and practices based on a worldwide survey. International Journal of Sustainable Development and World Ecology 21/5: 430-448. 